\section{Understanding Irrigation Water Applied, Consumptive Water Use, and Water Footprint Using Case Studies for Container Nursery Production and Greenhouse Crops}

\author{
Joshua Knight ${ }^{1}$, Dewayne L. Ingram ${ }^{1,3}$, and Charles R. Hall ${ }^{2}$
}

\begin{abstract}
ADDITIONAL INDEX WORDs. blue water, green water, gray water, nursery crops, recycled water

SUMMARY. The understanding, calculation, and comparison of water footprint (WF) among specialty crop growers are confounded by geography, species, and process. This study builds on published models of representative plant production systems developed using life cycle assessment. These models include container production using recycled water in the mid-Atlantic, southeastern, and Pacific northwestern regions of the United States and greenhouse production implementing rainfall capture and overhead and ebb/flood irrigation strategies. Production systems using recycled water compare favorably in consumptive water use (CWU) with those that do not, regardless of the water source. Production systems in geographic locations with high water availability compare favorably with production systems in locations with high water scarcity in WF, but not necessarily CWU.
\end{abstract}

$\mathrm{P}$ eople consume and pollute freshwater, and, globally, most water use occurs in agriculture (Aldaya et al., 2012). About $80 \%$ of CWU in the United States is for agriculture; however, if states are looked at individually, agricultural use accounts for $90 \%$ of all consumptive use for many western states (U.S. Department of Agriculture, 2019). The organization and characteristics of a production system strongly influence the water consumption associated with a final consumer product (Aldaya et al., 2012). With the rise of regional markets and emergence of international trade in water-intensive goods (including agricultural

Received for publication 1 Feb. 2019. Accepted for publication 12 Apr. 2019.

Published online 5 August 2019

This material is based on work that is supported by the National Institute of Food and Agriculture, U.S. Department of Agriculture, Specialty Crop Research Initiative, under award number 2014-51181-22372.

This paper is based on information presented during the Clean WateR3 program sessions, held as part of the ASHS Annual Conference, 30 July-3 Aug. 2018, in Washington, DC.

${ }^{1}$ Department of Horticulture, University of Kentucky, N-318 Ag Sciences Center, Lexington, KY 40546

${ }^{2}$ Professor and Ellison Chair in International Floriculture, Department of Horticultural Sciences, Texas A\&M University, 2133 TAMU, College Station, TX 77843

${ }^{3}$ Corresponding author. E-mail: dingram@uky.edu.

This is an open access article distributed under the CC BY-NC-ND license (https://creativecommons.org/ licenses/by-nc-nd/4.0/).

https://doi.org/10.21273/HORTTECH04290-19 products), use of water resources has become geographically distant from consumers (Aldaya et al., 2012). Chapagain and Hoekstra (2008) demonstrated that describing the hidden water use behind products can assist in the understanding and management of worldwide freshwater resources. Knowing a product's real water cost can influence consumer attitudes on the market. The objective of this article was to present analytical terms to characterize water management and present case studies to illustrate those terms.

Irrigation water applied (IWA) is a term defining the volume of water applied through irrigation during crop production. Green water refers to the volume of water used during production provided directly by rainfall. Blue water refers to the volume of water added to the system from streams, municipal sources, underground stores, and captured rainfall runoff. Gray water is a measure of contaminants in water leaving the system, expressed as the volume of water required to dilute any discharges to acceptable quality standards. Total CWU is the volume of green, blue, and gray water that has been used during plant production, as it is characterized by its environmental impact and exclusive use. Irrigation water applied does not take water recycling into account, whereas CWU does. Water footprint is the volume of CWU multiplied by the corresponding watershed's scarcity index (in the month the water was consumptively used), as calculated by the Available Water Remaining (AWARE) method (Boulay et al., 2017).

\section{Materials and methods}

Production system models were developed for a) container production of a \#3 (3.0 gal) japanese holly (Ilex crenata) in the mid-Atlantic United States with irrigation from surface water, b) container production of a \#3 japanese boxwood (Buxus microphylla) in the Pacific northwest United States with irrigation from surface water, c) greenhouse production of a 72-cell tray annual foliage using overhead irrigation sourced from well water in central Florida, and $d$ ) greenhouse production of a 72-cell tray annual foliage using ebb and flood sourced from rainfall capture in central Florida (Table 1). These production system models were based on best management practices for their location and interviews conducted with nursery and greenhouse managers in the region to validate the cultural practices in the production life cycle, input products used and labor required during each activity, equipment use, heating and cooling requirements, and water use for each operation (Ingram et al.,

\begin{tabular}{lllc}
\hline $\begin{array}{l}\text { Units } \\
\text { To convert U.S. to SI, } \\
\text { multiply by }\end{array}$ & U.S. unit & SI unit & $\begin{array}{l}\text { To convert SI to U.S., } \\
\text { multiply by }\end{array}$ \\
\hline 0.4047 & acre $(\mathrm{s})$ & $\mathrm{ha}$ & 2.4711 \\
254.0000 & acre-inch/acre & $\mathrm{m}^{3} \cdot \mathrm{ha}^{-1}$ & 0.0039 \\
102.7902 & acre-inch $(\mathrm{es})$ & $\mathrm{m}^{3}$ & 0.0097 \\
0.3183 & $\mathrm{fl} \mathrm{oz} / \mathrm{ft}^{2}$ & $\mathrm{~L}^{-2}$ & 3.1414 \\
0.3048 & $\mathrm{ft}$ & $\mathrm{m}$ & 3.2808 \\
0.0929 & $\mathrm{ft}$ & $\mathrm{m}^{2}$ & 10.7639 \\
3.7854 & gal & $\mathrm{L}$ & 0.2642 \\
0.0094 & gal/acre & $\mathrm{m}^{3} \cdot \mathrm{ha}^{-1}$ & 106.9066 \\
2.54 & inch(es) & $\mathrm{cm}$ & 0.3937 \\
25.4 & inch $(\mathrm{es})$ & $\mathrm{mm}$ & 0.0394 \\
1 & ppm & $\mu \mathrm{g}^{2} \cdot \mathrm{g}^{-1}$ & 1
\end{tabular}

Hortlechnology • December 2019 29(6) 
Table 1. Characteristics of nursery and greenhouse production case studies used in modeling consumptive water use and water footprint.

Case study
designation

sousthwest Uni

Southwest United States

Mid-Atlantic United States

Pacific northwest United States

Southeastern United States-old

Southeastern United States-new

${ }^{\mathrm{z}} 1$ acre $=0.4047$ ha

2016, 2017a, 2017b). Life cycle assessment standards were followed, including the International Organization for Standardization [Geneva, Switzerland (ISO, 2006)]. Information was extracted from these published models and from available geophysical water data, Geographical Information System spatial watershed analyses, and the latest 30-year climate normals from nearby monitoring stations for rainfall and rainfall intensity (Arguez et al., 2010).

Mid-Atlantic United States. The boundaries for this system assumed japanese holly cuttings would be taken from existing stock in February, stuck (two cuttings per $8-\mathrm{cm}$ cell) in a flat, and placed in a Quonset greenhouse with bottom heat in the coastal mid-Atlantic region (Ingram et al., 2016). Cuttings would be misted until rooted and then irrigated as needed. An average of 0.25 inch of irrigation was assumed to be applied daily for 32 weeks or 1.42 acre-inches per house. The liner would be transplanted to a \#3 container in September/October and grown for an additional 24 months on an outdoor gravel bed. Although the common application of 0.75 inch of water to be applied 280 times per year to the bed by overhead irrigation was assumed for this study, it has been shown that the daily water use may be $30 \%$ to $70 \%$ less depending on the crop (Warsaw et al., 2009). Outdoor and indoor irrigation would be pumped from a series of retention ponds with chlorine injection to yield 1-2 ppm free chlorine at the emitter. Runoff irrigation would be captured for reuse in retention ponds. The substrate would consist of aged pine bark. Warsaw et al. (2009) reported
$60 \%$ of water applied from overhead irrigation to \#3 containers spaced 18 inches on center ran off the bed.

Pacific northwest United States. Similar to the functional unit of the mid-Atlantic U.S. production system, the Pacific northwest U.S. system was based on an inventory and analysis of a model production system in the Pacific northwest of japanese boxwood in a \#3 container (Ingram et al., 2017a). Cuttings were taken in September and stuck directly in 40-cell flats in a greenhouse under mist, moved to a plastic-covered hoop house in the following spring, and grown for 11 months before being transplanted into \#l (1.0 gal) containers in the spring of year 2 . They would be transplanted to \#3 containers in the spring of year 3 and grown for an additional 18 months. Well water was used during the tray phase at a rate of 0.2 inch per day for 6 months, followed by 0.75 inch per day in the hoop house for the next 13 months. Once transplanted into \#1 containers, they would be irrigated at a rate of 0.75 inch per day, which would continue through the \#3 container phase of production. Irrigation during outdoor production on gravel beds was assumed to be from surface reservoirs and retention ponds designed to catch irrigation and rainfall runoff. During outdoor production, irrigation events would only occur four times from October through March in a given year. From April through September, irrigation would run every other day.

SOUTHEASTERN U.S. NEW AND SOUTHEASTERN U.S. OLD. For both systems, located in the southeastern United States, young plants would be transplanted as tissue-cultured micro- cuttings, misted for 4 weeks, and grown for an additional 8 weeks before marketing (Ingram et al., $2017 \mathrm{~b}$ ). Both modeled facilities were closed systems, so the irrigation and misting caused no runoff from the greenhouses. Water would also be used for evaporative cooling through fan and pad systems operating 9 months per year for an average of $8 \mathrm{~h}$ per day. Based on grower interviews, water use for evaporative cooling was assumed to be 10.7 and $16.3 \mathrm{fl}$ $\mathrm{oz} / \mathrm{ft}^{2}$ for older and newer systems, respectively.

These systems differed by greenhouse type, bench size, arrangement, and rainwater capture. The old system was modeled as an older, gutter-connected, rounded-arch, 60,000- $\mathrm{ft}^{2}$ greenhouse without a ridge vent, with a double layer of polyethylene film on the roof, biwall polycarbonate sidewalls, and a 3-m gutter height. A shadecloth was installed inside the house. The $624-\mathrm{ft}^{2}$ benches would be stationary and hold 36572 -cell trays $(21.2 \times 11.0$ inches $)$ each. Irrigation in the old would be provided via overhead spray nozzles applying 200 gal per bench per irrigation. The benches would be irrigated 28 times for $10 \mathrm{~min}$ each for a total of $17 \mathrm{gal}$ per tray during the 8 -week production cycle. The fan and pad evaporative cooling system would operate an average of 8 h per day.

The new system was modeled as a more modern gutter-connected, Dutch-style greenhouse using natural ventilation with roof vents and retractable shade interior to the house controlled by an integrated environmental control system. The 110,000$\mathrm{ft}^{2}$ greenhouse would be designed with a gutter system to capture rainfall to be stored in 500,000-gal tanks. Water captured from the roof would be treated and used in an ebb-flood system. It was assumed that 64 gal was required to flood each bench for 26 irrigations and $80 \%$ would be returned to the holding tank.

Calculating WF. Consistent with the concept of WF, all components of a total WF were specified geographically and temporally (Aldaya et al., 2012). WF is the total volumetric CWU required to produce a product weighted temporally and geospatially characterized by the water scarcity indices calculated by the AWARE method (Boulay et al., 
2017) for each month of water use in the watershed. WF is the sum of four components: embodied water, green water, blue water, and gray water: $\mathrm{WF}_{\text {Total }}=\mathrm{WF}_{\text {Embodied }}+\mathrm{WF}_{\text {Green }}+$ $\mathrm{WF}_{\text {Blue }}+\mathrm{WF}_{\text {Gray }}$.

WF Embodied, sometimes referred to as "virtual water," is the weighted volume of water used to produce and deliver input components of production, including pesticides, containers, and herbicides. $\mathrm{WF}_{\mathrm{Green}}$ is the unweighted volume of water used, as precipitation, required to produce a product (Aldaya et al., 2012). $\mathrm{WF}_{\text {Green }}$ was calculated as the volume of water used, per plant, in avoided irrigation events due to precipitation. $\mathrm{WF}_{\text {Blue }}$ is the weighted volume of water used from ground, surface, and/or any municipal sources. Rainfall captured in a pond or artificial catchment contributes to $\mathrm{WF}_{\text {Blue }}$. $\mathrm{WF}_{\text {Blue }}$ was first determined by calculating the total captured rainfall and added water in a production system each month for the modeled length of production, and then dividing by the total number of plants. This yielded an unweighted volume of consumptive blue water use. The same process was repeated but with the volume weighted according to the latest method (AWARE) to characterize the scarcity of water based on local specific conditions (Boulay et al., 2017). $\mathrm{WF}_{\text {Gray }}$ is the weighted volume of water required to dilute any discharges from the operation. As interviews and monitoring information related to pollutant load for water leaving our studied plant nurseries were unavailable, $\mathrm{WF}_{\text {Gray }}$ was not calculated. In closed systems, such as greenhouses that do not discharge water, there is no $\mathrm{WF}_{\mathrm{Green}}$ or $\mathrm{WF}_{\mathrm{Gray}}$.

CAPTURED RAINFALl RUNOFF. Monthly rainfall amounts and intensities were based on 30-year averages from 1981 to 2010 from the National Oceanic and Atmospheric Administration Climate Data Center (Ansorge and Beránková, 2017). For the two outdoor nurseries with catchment ponds facilitating recycled water use by catching irrigation and rainfall runoff for irrigation, ArcMap 10.3.1 (Environmental Systems Research Institute, Redlands, CA) was populated with remote sensing Light Detection and Ranging data (U.S. Geological Survey, 2017). Data points were filtered to show only ground-level returns (Maune et al., 2001) and then analyzed using automated hydrology tools to define the boundaries of the catchment area (Kost and Kelly, 2001).

Satellite imagery of the nursery surface was characterized into functional groups related to rainfall runoff: reservoir, impervious/engineered space, and engineered space. These groups were further subdivided and assigned a runoff value based on more specific characterization (Table 2). This value reflects what percentage of water would run off and be eligible for capture by the catchment area after the first 0.5 inch of rainfall for engineered surfaces and 1 inch for unengineered surfaces in a given 24$\mathrm{h}$ period. Runoff percentages were assigned using calculations from a composite soil survey of the location in combination with the characterization of the surface type (Cronshey, 1986). The area for each cover type was used as a proportion of the overall catchment area to develop a composite runoff coefficient for the rainfall intensities available in 30 -year averages.

A water budget incorporating total water capacity and expected losses from the reservoir due to evaporation and infiltration was developed to estimate the potential for uncaptured water during rainfall events. Water that is not captured by the catchment area but continues to flow downstream does not count toward $\mathrm{WF}_{\text {Blue }}$.

STANDARDIZATION ACROSS VARYING PRODUCTION SYSTEMS. A specific container-grown plant was not

Table 2. Runoff percentages based on land cover type used to populate models for rainfall and irrigation capture in case studies of nursery and greenhouse production.

\begin{tabular}{llr}
\hline Group & \multicolumn{1}{c}{ Cover type } & Runoff (\%) \\
\hline Reservoir & Surface water & 100 \\
Impervious/engineered & Production beds & 80 \\
& Buildings/plastic/concrete & 100 \\
& Gravel pathway/roads & 90 \\
Unengineered & Grass cover & 77 \\
& Brush, field nursery, woods & 73 \\
& Unassigned & 77 \\
\hline
\end{tabular}

Table 3. Consumptive water use (CWU) and water footprint (WF) per marketable plant in four nursery and greenhouse production case studies.

\begin{tabular}{|c|c|c|c|c|}
\hline Production system $^{z}$ & $\begin{array}{l}\text { \#3 Japanese } \\
\text { holly }^{\mathrm{y}}\end{array}$ & $\begin{array}{l}\text { \#3 Japanese } \\
\text { boxwood }^{\mathrm{y}}\end{array}$ & $\begin{array}{l}\text { 72-Cell tray } \\
\text { overhead }^{\mathrm{x}}\end{array}$ & $\begin{array}{l}\text { 72-Cell tray ebb and } \\
\text { flood }^{\mathrm{w}}\end{array}$ \\
\hline Green water volume (gal) & 21.2 & 10.5 & 0.0 & 0.0 \\
\hline $\begin{array}{l}\text { Total consumptive water use } \\
\quad(\mathrm{gal})\end{array}$ & 254 & 130 & 39.0 & 30.5 \\
\hline Water scarcity indices ${ }^{\mathrm{v}}$ & 0.77 & 1.16 & 1.24 & 1.24 \\
\hline Total WF (weighted gal) & 201 & 164 & 48.4 & 37.9 \\
\hline
\end{tabular}

${ }^{\mathrm{z}}$ Green water is the irrigation volume avoided by rainfall events. Blue water is the volume of water added to the system from streams, municipal sources, underground stores, and captured rainfall runoff; $1 \mathrm{gal}=3.7854 \mathrm{~L}$.

yapanese holly production was from a mid-Atlantic U.S. model; japanese boxwood was from a Pacific northwest model; \#3 = 3.0-gal container.

${ }^{\mathrm{x}} 72$-cell tray of young foliage plants in an older greenhouse system with overhead irrigation in the southeastern United States.

w72-cell tray of young foliage plants in a newer greenhouse system with ebb-and-flood irrigation in the southeastern United States.

${ }^{\mathrm{v}}$ Calculated using the Available Water Remaining (AWARE) method (Boulay et al., 2017). 


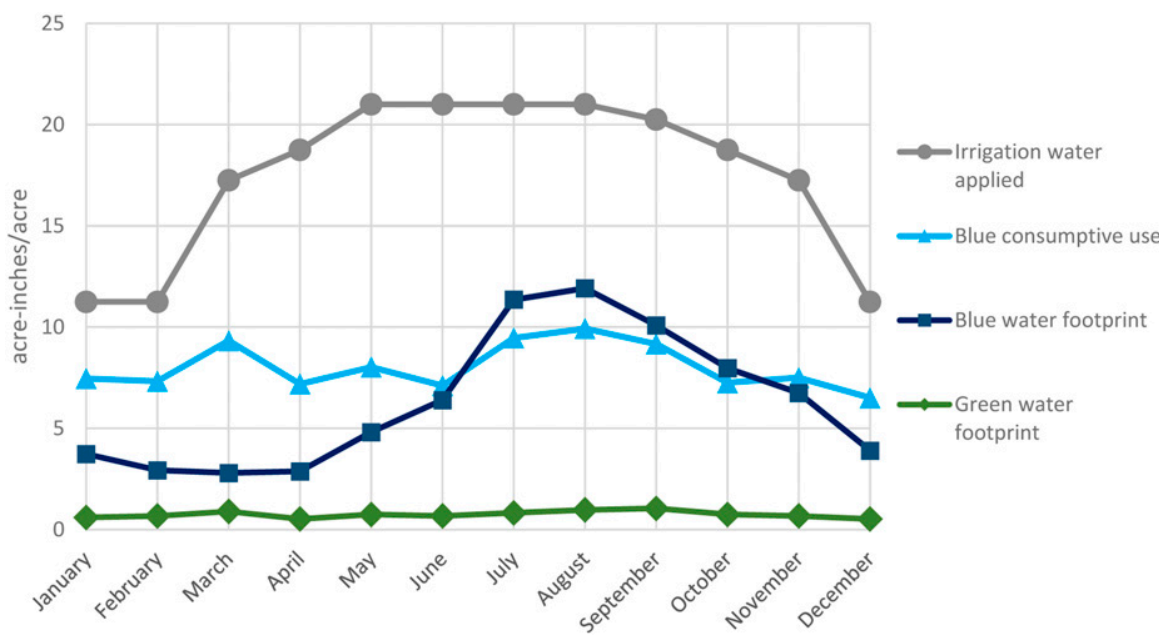

Fig. 1. Monthly irrigation water applied, green water footprint (WF), consumptive blue water use, and blue WF for the mid-Atlantic U.S. container nursery production case study for japanese holly in \#3 containers [3 gal (11.4 L)]. Irrigation water applied is the volume of irrigation. Consumptive blue water use is the volume of irrigation applied adjusted for recycling. Blue WF is the consumptive water use modified by the monthly water scarcity (AWARE method) for the specific location (Boulay et al., 2017); 1 acre-inch $/$ acre $=27,154.3 \mathrm{gal} /$ acre $=254.0 \mathrm{~m}^{3} \cdot \mathrm{ha}^{-1}$.

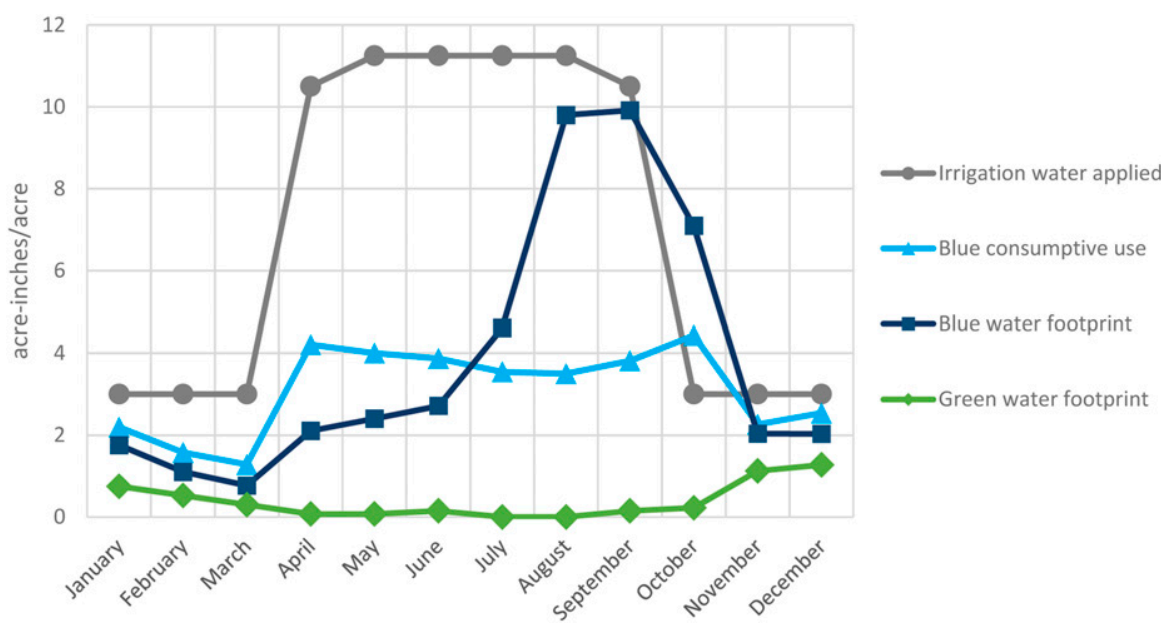

Fig. 2. Monthly irrigation water applied, green water footprint (WF), consumptive blue water use, and blue WF for the Pacific northwest U.S. container nursery production case study for japanese boxwood in \#3 containers [ 3 gal (11.4 L)]. Irrigation water applied is the volume of irrigation. Consumptive blue water use is the volume of irrigation applied adjusted for recycling. Blue WF is the consumptive water use modified by the monthly water scarcity (AWARE method) for the specific location (Boulay et al., 2017); 1 acre-inch/acre $=27,154.3 \mathrm{gal} /$ acre $=254.0 \mathrm{~m}^{3} \cdot \mathrm{ha}^{-1}$.

modeled for the southwest U.S. case study, making the comparison of IWA, CWU, and WF on a per-plant basis problematic. However, the knowledge of areas of each watershed and sub-watershed allowed the expression of water use characteristics of each case study to be modeled on an acre-inches per irrigated acre basis.

\section{Results and discussion}

\#3 Container systems, EAst vs. WEST. Consumptive water use to produce a \#3 japanese holly on the east coast of the United States was 254 gal, with green water and blue water use of 21.2 and 233 gal, respectively. A \#3 japanese boxwood produced on the west coast of the United States had a total CWU of $130 \mathrm{gal}$, with 10.5 and 119 gal for green water and blue water use, respectively (Table 3 ; Figs. 1 and 2).

The $\mathrm{WF}_{\text {Total }}$, or CWU weighted by relative scarcity, was 201 gal with a $W_{\text {Green }}$ of $21.2 \mathrm{gal}$ and a $W_{\text {Blue }}$ of $180 \mathrm{gal}$ for the U.S. east coast production of \#3 japanese holly. The \#3 japanese boxwood produced on the U.S. west coast yielded a $\mathrm{WF}_{\text {Green }}$ of $10.5 \mathrm{gal}$ and a $W_{\text {Blue }}$ of $154 \mathrm{gal}$ (Table 3).

The production system of the east coast of the United States objectively used $96 \%$ more water than the water-scarce production system of the west coast of a similar plant with a similar production cycle, in a direct comparison of volume usage. As $\mathrm{WF}_{\text {Green }}$ is unweighted, the CWU for green water and $\mathrm{WF}_{\mathrm{Green}}$ are the same value. The $\mathrm{WF}_{\mathrm{Green}}$ for the west coast was $49.4 \%$ of the $\mathrm{WF}_{\text {Green }}$ for the east coast. This is unsurprising given the likelihood of rainfall resulting in an avoided irrigation event being much higher on the east coast than the west coast, and only means an overall difference of $10.7 \mathrm{gal}$ of water between the two systems. Unweighted blue water use represents the largest driver $(91 \%)$ of the difference between the CWU of each system, with blue water volume of \#3 japanese holly on the east coast using 95\% more than \#3 japanese boxwood on the west coast. However, it should be noted that the model systems assumed more efficient irrigation management in the west coast model. Irrigation management alone can decrease the WF of container-grown plants.

Weighting the differences by multiplying the CWU by the water scarcity indices calculated using the AWARE method according to geographic and temporal scarcity to generate $\mathrm{WF}_{\text {Total }}$ for each production system brings the comparison closer in value, with the water-rich \#3 japanese holly on the east coast only having a $\mathrm{WF}_{\text {Total }} 22 \%$ more than \#3 japanese boxwood on the west coast. In the weighted comparison, $\mathrm{WF}_{\mathrm{Blue}}$ still plays the dominant role, representing $71 \%$ of the difference in $\mathrm{WF}_{\text {Total }}$.

YOUNG PLANTS, 72-CELL TRAYS IN THE SOUTHEASTERN UNITED States. As both production systems are closed, there is no green or gray 


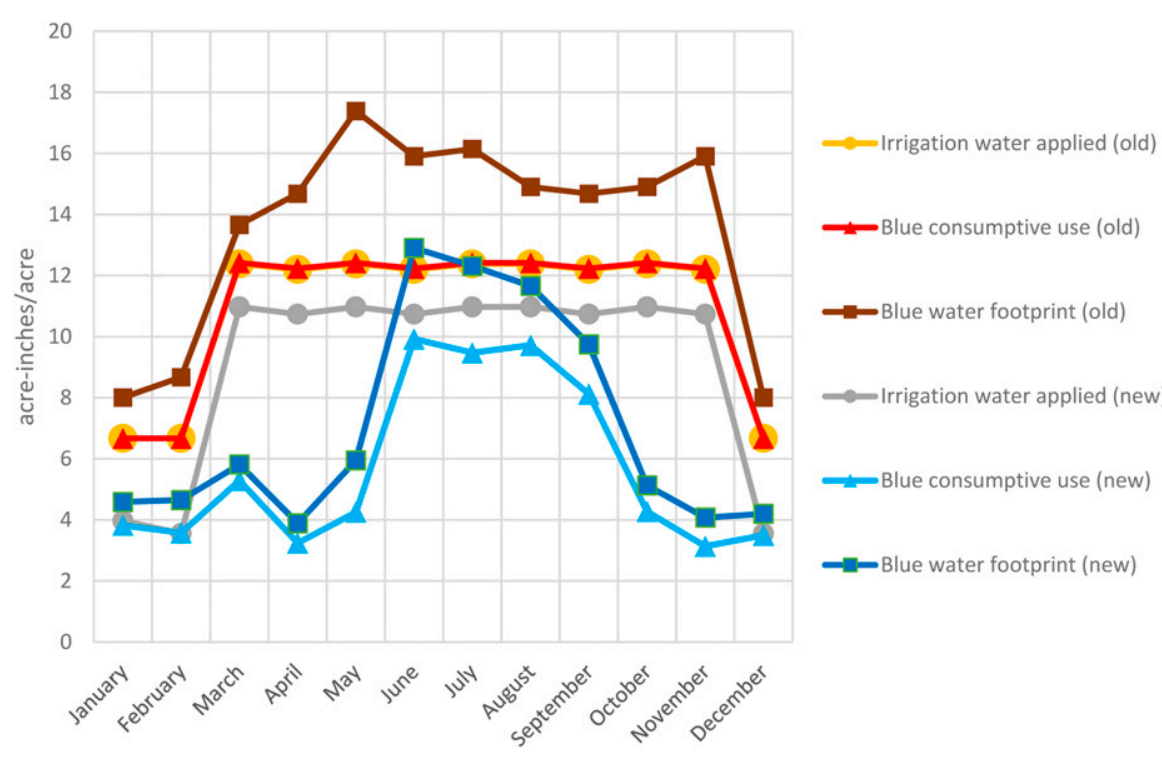

Fig. 3. Monthly consumptive blue water use and blue water footprint (WF) for 72 -cell foliage plants in old and new greenhouse production case studies in the southeastern United States. Irrigation water applied is the volume of irrigation. Consumptive blue water use is the volume of irrigation applied adjusted for recycling. Blue WF is the consumptive water use modified by the monthly water scarcity (AWARE method) for the specific location (Boulay et al., 2017); 1 acreinch $/$ acre $=27,154.3 \mathrm{gal} /$ acre $=254.0 \mathrm{~m}^{3} \cdot \mathrm{ha}^{-1}$.

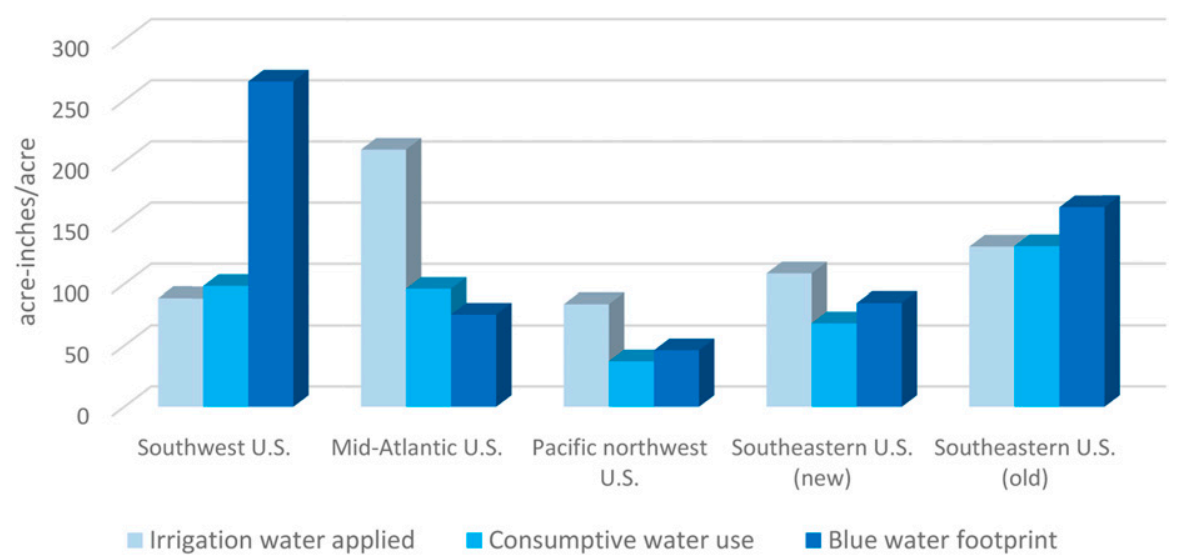

Fig. 4. Annual irrigation water applied, consumptive blue water use, and blue water footprint for five U.S. nursery and greenhouse case studies. Irrigation water applied is the volume of irrigation. Consumptive blue water use is the volume of irrigation applied adjusted for recycling. Blue water footprint is the consumptive water use modified by the monthly water scarcity (AWARE method) for the specific location (Boulay et al., 2017); 1 acre-inch $/$ acre $=27,154.3$ gal $/$ acre $=$ $254.0 \mathrm{~m}^{3} \cdot \mathrm{ha}^{-1}$.

water volume. The older greenhouse using overhead irrigation used 39.0 gal of blue water, whereas the newer greenhouse used $30.5 \mathrm{gal}$ or $28 \%$ less (Table 3). When weighting for scarcity, the $\mathrm{WF}_{\text {Blue }}$ for the older greenhouse and new greenhouse was 48.4 and 38.0 gal, respectively. Further analysis of the contribution revealed differences in water use by phase of system used 5.6 gal per tray, making this phase of production $204 \%$ more efficient with CWU. However, the swamp cooler system for the new greenhouse used 18.5 gal whereas the older greenhouse used 15.2 gal. This difference is likely caused by the increased reliance on evaporative cooling for temperature reduction in the newer greenhouse and does not offset the water savings from increased greenhouse space efficiency and water recycling capacity of the ebb-and-flood system.

WATER MANAGEMENT AND PERFORMANCE COMPARISON OF ALL SYSTEMS. Irrigation water applied was 210 acre-inches/acre for the midAtlantic U.S. case (among the container nurseries and overall), confirming its characterization as an abundant water user. Water use for all others was much lower, with 88.7 acre-inches/ acre for the southwest United States, 84.0 acre-inches/acre for the Pacific northwest United States, 131 acreinches/acre for the old greenhouse in the southeastern United States, and 108 acre-inches/acre for the new greenhouse in the southeastern United States (Fig. 4).

Across all case studies, the highest blue CWU was found in the older greenhouse production system of the southeastern United States, with a total annual CWU of 131 acre-inches/ acre of irrigated space (Table 4; Fig. 4). This is logical because greenhouse environments are engaged in intensive production year-round, with this older greenhouse irrigating directly from a blue water source without recycling. The distinction between blue CWU and blue WF between the two greenhouse systems becomes clearer when volumes are compared on a monthly basis (Fig. 3). The CWU in the older greenhouse would be consistent throughout the year if water use by the evaporative cooling system was excluded. Evaporative cooling accounted for 36.8 acreinches/acre in the old greenhouse. The updated greenhouse in the same location, relying on captured rainfall runoff and using an ebb-and-flood recycling system, reduces this total annual CWU to 68.3 acre-inches/ acre of irrigated space, with 23.4 acre-inches/acre of that total being used by the swamp cooler.

Green CWU was above zero in only two case studies: mid-Atlantic 
Table 4. Annual irrigation water applied (IWA), consumptive water use (CWU), and water footprint (WF) for four nursery and greenhouse production case studies.

\begin{tabular}{|c|c|c|c|}
\hline \multirow[b]{2}{*}{ Case study } & Irrigation water applied ${ }^{\mathrm{z}}$ & Consumptive water use & Blue WF \\
\hline & \multicolumn{3}{|c|}{ (acre-inches/acre) $^{\mathrm{y}}$} \\
\hline Southwest United States & 88.7 & 98.7 & 266 \\
\hline Pacific northwest United States & 84.0 & 37.2 & 46.3 \\
\hline Southeastern United States_-old & 109 & 68.3 & 85.0 \\
\hline Southeastern United States-old & 131 & 131 & 163 \\
\hline
\end{tabular}

${ }^{\mathrm{z}}$ Irrigation water applied is the volume of irrigation. Consumptive water use is the volume of irrigation applied adjusted for recycling. Blue WF is the consumptive water use modified by the monthly water scarcity (AWARE method) for the specific location (Boulay et al., 2017).

${ }^{\mathrm{y}} 1 \mathrm{acre}$-inch $/$ acre $=27,154.3 \mathrm{gal} /$ acre $=254.0 \mathrm{~m}^{3} \cdot \mathrm{ha}^{-1}$.

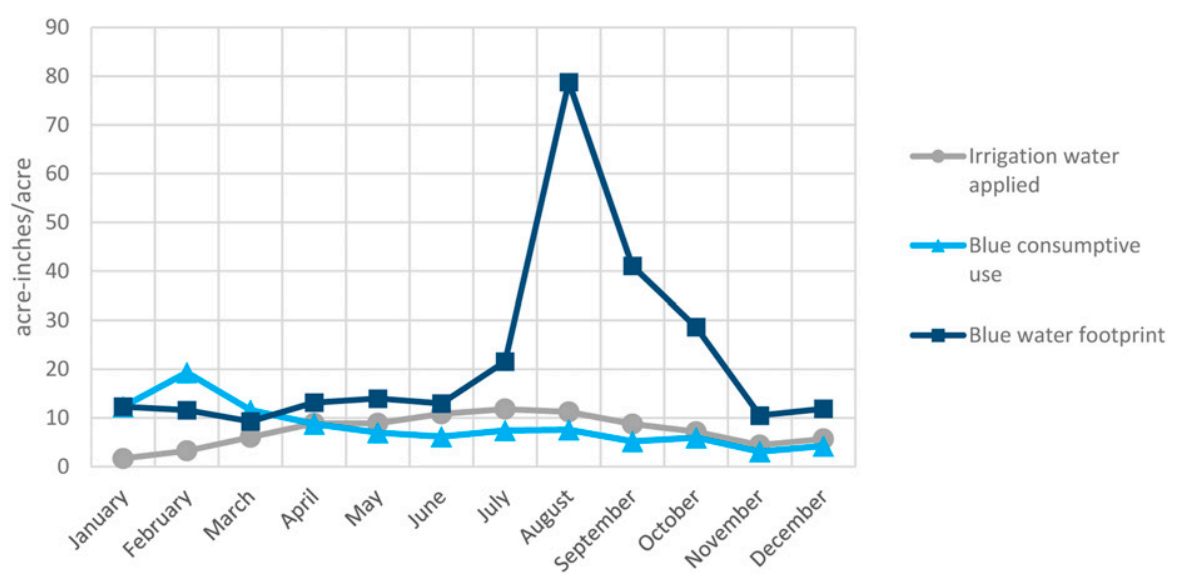

Fig. 5. Monthly irrigation water applied, consumptive blue water use, and blue water footprint (WF) for the southwest U.S. container nursery production case study. Irrigation water applied is the volume of irrigation. Consumptive blue use is the volume of irrigation applied adjusted for recycling. Blue WF is the consumptive water use modified by the monthly water scarcity (AWARE method) for the specific location (Boulay et al., 2017); 1 acre-inch $/$ acre $=27,154.3 \mathrm{gal} /$ acre $=254.0 \mathrm{~m}^{3} \cdot \mathrm{ha}^{-1}$.

and Pacific northwest, where it amounted to 8.9 and 4.6 acreinches/acre, respectively. The Pacific northwest production system was the most efficient consumer of blue water across the case studies, using only 37.2 acre-inches/acre of irrigated space in a year, whereas the southwest and mid-Atlantic locations used 98.7 and 96.2 acre-inches/acre, respectively. When these CWU volumes are weighted according to the monthly water scarcity indices for each month the water was consumed to calculate an annual $\mathrm{WF}_{\mathrm{Blue}}$ for each case study, the southwest U.S. production system had the greatest effect using 265 weighted acre-inches/irrigated acre, whereas the mid-Atlantic production system was reduced by weighting to 75.5 acre-inches/irrigated acre because of the higher relative availability of water (Fig. 4). The timing of the scarcity effects on $\mathrm{WF}_{\mathrm{Blue}}$ is easily demonstrated by comparing the monthly breakdown of volumes for southwestern U.S. (Fig. 5), mid-Atlantic U.S. (Fig. 1), Pacific northwest (Fig. 2), and the southeastern systems, respectively (Fig. 3). The distinction between $\mathrm{CWU}$ and $\mathrm{WF}_{\mathrm{Blue}}$ is clearly visible during the driest season from July through October in the southwest U.S. case study when water is least available (Fig. 5 ).

In further research and comparison of CWU and WF in horticultural production systems, economic and marketable biomass data would allow for a more robust characterization of water management economic efficiency or plant productivity for similar case studies. This would control for the increased water use of higher intensity production systems such as those found in greenhouses and in climates with year-round production, to allow for a closer comparison between production systems.

\section{Literature cited}

Aldaya, M.M., A.K. Chapagain, A.Y. Hoekstra, and M.M. Mekonnen. 2012. The water footprint assessment manual: Setting the global standard. Routledge, London, UK.

Ansorge, L. and T. Beránková. 2017. LCA water footprint AWARE characterization factor based on local specific conditions. Eur. J. Sustain. Dev. 6:13-20.

Arguez, A., I. Durre, S. Applequist, M. Squires, R. Vose, X. Yin, and R. Bilotta. 2010. NOAA's U.S. climate normals (1981-2010). Natl. Oceanic Atmospheric Administration Natl. Ctr. Environ. Info. 10:V5PN93JP.

Boulay, A.M., J. Bare, L. Benini, M. Berger, M.J. Lathuillière, A. Manzardo, M. Margni, M. Motoshita, M. Núñez, A.V. Pastor, and B. Ridoutt. 2017. The WULCA consensus characterization model for water scarcity footprints: Assessing impacts of water consumption based on available water remaining (AWARE). Intl. J. Life Cycle Assess. 23:368-378.

Chapagain, A.K. and A.Y. Hoekstra. 2008. The global component of freshwater demand and supply: An assessment of virtual water flows between nations as a result of trade in agricultural and industrial products. Water Int. 33(1):19-32.

Cronshey, R. 1986. Urban hydrology for small watersheds. 2nd ed. U.S. Dept. Agr., Soil Conservation Serv., Eng. Div. Tech., Release 55, Washington, DC.

Ingram, D.L., C.R. Hall, and J. Knight. 2016. Carbon footprint and variable costs of production components for a container-grown evergreen shrub using life cycle assessment: An east coast U.S. model. HortScience 51:989-994.

Ingram, D.L., C.R. Hall, and J. Knight. 2017a. Comparison of three production scenarios for Buxus microphylla var. japonica 'Green Beauty' marketed in a \#3 container on the west coast using life cycle assessment. HortScience 52:357-365. 
Ingram, D.L., C.R. Hall, and J. Knight. $2017 \mathrm{~b}$. Modeling global warming potential, variable costs, and water use of young plant production system components using life cycle assessment. HortScience 52:1356-1361.

International Organization for Standardization. 2006. Life cycle assessment, requirements and guidelines. ISO Rule 14044:2006. Intl. Organization for Standardization, Geneva, Switzerland.
Kost, J.R. and G.G. Kelly. 2001. Watershed delineation using the National Elevation Dataset and semiautomated techniques. Proc. 2001 ESRI Intl. User Conf. p. 9-13.

Maune, D.F., J.B. Maitra, and E.J. McKay. 2001. Accuracy standards, p. 6182. In: D.F. Maune and A. Nayegandhi (eds.). Digital elevation model technologies and applications: The DEM users' manual. Amer. Soc. Photogrammetry Remote Sensing Publ., Bethesda, MD.
U.S. Geological Survey. 2017. 3D Elevation Program. 1 Nov. 2018. <https:// nationalmap.gov/3 DEP/3 dep_ prodserv.html>.

U.S. Department of Agriculture. 2019. Irrigation \& water use. 9 Jan. 2019. <https://www.ers.usda.gov/topics/ farm-practices-management/irrigationwater-use $/>$.

Warsaw, A.L., R.T. Fernandez, B.M. Cregg, and J.A. Andersen. 2009. Container-grown ornamental plant growth and water runoff nutrient content and volume under four irrigation treatments. HortScience 44:1573-1580. 